\title{
Review \\ Bench-to-bedside review: Clostridium difficile colitis
} Carolyn V Gould and L Clifford McDonald

\author{
Prevention and Response Branch, Division of Healthcare Quality Promotion, Centers for Disease Control and Prevention, Clifton Road NE, Atlanta, GA \\ 30333, USA
}

Corresponding author: L Clifford McDonald, CMcDonald1@cdc.gov

Published: 18 January 2008

This article is online at http://ccforum.com/content/12/1/203

Critical Care 2008, 12:203 (doi:10.1186/cc6207)

(c) 2008 BioMed Central Ltd

See related commentary by Pop-Vicas and Neill, http://ccforum.com/content/12/1/114

\begin{abstract}
In recent years, the incidence and severity of Clostridium difficileassociated disease (CDAD) have increased dramatically. Beginning in 2000, widespread regional outbreaks associated with a previously uncommon hypervirulent strain of C. difficile have occurred in North America and Europe. Most likely because of increased toxin production as well as other virulence factors, this epidemic strain has caused more severe and refractory disease leading to complications, including intensive care unit admission, colectomies, and death. Worldwide increasing use of fluoroquinolones and cephalosporins has likely contributed to the proliferation of this epidemic strain, which is highly resistant to both. The elderly have been disproportionately affected by CDAD, but $C$. difficile has also recently emerged in populations previously considered to be at low risk, including healthy outpatients and peripartum women, although it is unknown if these cases are related to the epidemic strain. Nevertheless, transmission within hospitals is the major source of $C$. difficile acquisition, and previous or concurrent antimicrobial use is almost universal among cases. Applying current evidence-based strategies for management and prevention is critically important, and clinicians should maintain an awareness of the changing epidemiology of CDAD and take measures to reduce the risk of disease in patients.
\end{abstract}

\section{Background}

Since the discovery of Clostridium difficile-associated disease (CDAD) approximately 30 years ago $[1,2]$, much progress has been made in our understanding of the pathogenesis and management of this infection. In recent years, however, the epidemiology of $C$. difficile has changed dramatically. Beginning in 2000, widespread regional outbreaks of $C$. difficile strains involving more severe and refractory disease have occurred, with greater numbers of complications, colectomies, and deaths than previously described [3-6]. Since most $C$. difficile acquisitions occur within healthcare settings, emphasis should be placed on implementing evidence-based strategies for infection control and prevention, early detection, and effective treatment for severe and relapsing CDAD.

\section{Pathogenesis and epidemiology}

Toxin-producing strains of $C$. difficile, an anaerobic sporeforming bacillus, cause illnesses ranging from mild diarrhea to fulminant colitis and toxic megacolon leading to sepsis and even death. There are two essential requirements for CDAD to develop: exposure to antimicrobials and new acquisition of C. difficile, although the precise timing and order of these events is not well understood. An important third factor, possibly relating to host susceptibility or virulence factors of the bacterial strain, may then determine whether the clinical outcome will be asymptomatic colonization or CDAD [7].

Acquisition of C. difficile occurs by oral ingestion of spores, which resist the acidity of the stomach and germinate into the vegetative form in the small intestine. Disruption of the commensal flora of the colon, typically through exposure to antimicrobials, allows C. difficile to flourish and produce toxins that lead to colitis. The primary toxins produced are toxins $A$ and $B$, two large exotoxins that cause inflammation and mucosal damage. Both toxins appear to have cytotoxic effects through disruption of the actin cytoskeleton within cells [8]. Although previous evidence suggested that toxin $A$ is the major enterotoxin, $C$. difficile strains that produce toxin $B$ but not toxin $A$ have recently been isolated from patients with CDAD [9].

Nearly all antimicrobials have been implicated in the development of CDAD [10]. Certain antimicrobial classes that are broad-spectrum and have a propensity for killing colonic bacteria, especially cephalosporins, clindamycin, and most recently, fluoroquinolones, may pose a greater risk for the development of the disease. The other major risk factors for CDAD are advanced age and hospitalization [10]. In addition, severe underlying disease, immunocompromising conditions, chemotherapeutic drugs, gastrointestinal surgery, nasogastric tubes, and gastric acid suppression are pre- 
disposing factors [11,12]. Persons with normal healthy gastrointestinal flora and the ability to mount a brisk immune response are at lower risk for CDAD. Asymptomatic carriers of $C$. difficile have been found to have high levels of $\lg G$ antibodies to toxin $A$ and have a decreased risk of developing CDAD compared to non-carriers [13,14]. In addition, a vigorous serum antibody response to toxin $A$ during an initial episode of CDAD is associated with protection against recurrent disease [15].

Although community-acquired C. difficile is increasingly recognized, healthcare setting transmission is the primary mode of $C$. difficile acquisition. Only about 3\% of healthy adults in the community are colonized with C. difficile, compared to $20-40 \%$ of hospitalized patients $[16,17]$. The risk of C. difficile acquisition is also highly correlated with length of hospital stay [18]. The incubation period of C. difficile following acquisition has not been clearly defined. Although one study suggested an incubation period of less than seven days [19], there may be prolonged intervals between onset of diarrhea and hospital discharge or cessation of antimicrobials [20], emphasizing the need for a high level of suspicion for CDAD in patients presenting with diarrhea in the community following a hospital admission.

\section{Changing epidemiology}

In the last seven to eight years, the incidence and severity of C. difficile have increased dramatically. CDAD rates in intensive care units increased significantly from 1987 to 2001 in hospitals with greater than 500 beds [21]. In the United States, the number of hospital discharges where CDAD was listed as any diagnosis doubled between 2000 and 2003, with a disproportionate increase for persons aged $>64$ years [22] (Figure 1). By 2003, regional reports of CDAD outbreaks from hospitals throughout the US and in Quebec, Canada emerged, describing severe disease associated with greater numbers of complications, including colectomies, treatment failures, and deaths [3-5]. In 2004, the attributable mortality rate of nosocomial CDAD in Quebec hospitals was $6.9 \%$ [3], compared to $1.5 \%$ among Canadian hospitals in 1997 [23]. In the US, death certificate data suggest mortality rates due to CDAD increased from 5.7 per million population in 1999 to 23.7 per million in 2004 [24]. By contrast, a study in a US medical center in 1998 found no excess mortality attributable to CDAD after adjustment for confounding factors [25].

A hypervirulent epidemic strain of $C$. difficile was found to be associated with the outbreaks in the US and Quebec and subsequently with outbreaks in the United Kingdom and other parts of Europe $[3,4,26]$. The epidemic strain has been characterized as restriction enzyme analysis type Bl, North American Pulsed-Field Type 1 (NAP1), and PCR ribotype 027 [4,27]. Restriction enzyme analysis of the pathogenicity locus containing the toxin and associated regulatory genes also classifies this strain as toxinotype III, a previously
Figure 1

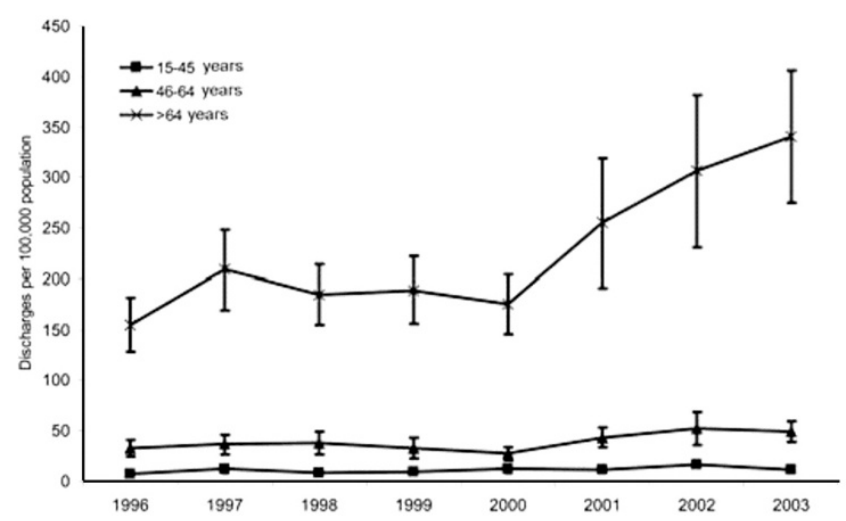

Rates of discharges from US short-stay hospitals of patients with C. difficile-associated disease listed as any diagnosis by age [22]

uncommon toxinotype among hospital strains [28]. The BI/NAP1/027 strain has been found to produce 16-fold higher concentrations of toxin $A$ and 23-fold higher concentrations of toxin B in vitro [27], a finding that is most likely related to the presence of an early frameshift mutation identified in $t c d C$ within the pathogenicity locus of this epidemic strain [29], since the product of the unaltered gene normally inhibits toxin production [30]. An 18 base pair deletion is also present within this gene in the epidemic strain but is downstream of the frameshift mutation and does not alter the function of the TcdC protein [30]. Another characteristic of the strain is the production of a toxin called binary toxin, the role of which is not yet defined; however, strains that produce the binary toxin may be associated with more severe diarrhea [31]. The cause of the extreme virulence of the BI/NAP1/027 strain may be a combination of increased toxins $A$ and $B$, binary toxin, or other features particular to toxinotype III strains.

Another feature related to the proliferation of this strain is its universal, high levels of resistance to fluoroquinolones, including the C-8-methoxyfluoroquinolones, moxifloxacin and gatifloxacin [4]. Although BI/NAP1/027 isolates existed previously, historic strains were less resistant to fluoroquinolones, and they were not associated with outbreaks of disease. The emergence of this strain now is likely related to its selective advantage in the presence of widespread increasing use of fluoroquinolones. A similar phenomenon was observed with the clindamycin-resistant 'J strain', which caused outbreaks in the late 1980s and early 1990s [32].

In addition to strain characteristics, host factors also play a major role in CDAD, and the elderly have been particularly affected. In recent studies, CDAD rates, severity, and mortality have been highest in persons $>65$ years of age $[3,6,22,24]$. C. difficile is a significant cause of outbreaks and non-epidemic diarrhea in nursing homes [33,34]. The 
association of CDAD with advanced age may be a result of a weaker immune response to $C$. difficile or other underlying illnesses. However, C. difficile has also recently emerged in populations previously considered to be at low risk, including healthy outpatients, peripartum women, children, and people with no recent antibiotic exposure [35]. More research is needed to determine if these cases are due to strains carrying similar virulence factors to the BI/NAP1/027 strain.

\section{Diagnosis}

Early diagnosis is key to preventing complications from severe CDAD and preventing transmission. Rapid diagnosis depends on maintaining a high degree of clinical suspicion for CDAD in patients with diarrhea and recent antimicrobial exposure and hospitalization. The tissue culture cytotoxic assay has long been considered the gold standard diagnostic test but is limited by slow turnaround time (at least 48 hours), work intensity, and cost [8]. The enzyme immunoassay for detection of toxins $A$ and $B$ is the most commonly used test in clinical laboratories because of its ease of use and rapidity. Although the test is highly specific, it has a lower sensitivity (70-87\%) than the cytotoxic assay [36-39]. However, testing two or three stool specimens can increase the yield by $10 \%$ or more [39]. Assays that test for both toxins $A$ and $B$ are required to detect toxin $A-B+$ strains.

The detection of $\mathrm{C}$. difficile by culture is rarely performed for diagnostic purposes because it is labor intensive and has a slow turnaround time. However, if culture is combined with toxin testing of the recovered isolate (so-called 'toxigenic culture'), it may be even more sensitive than the tissue cytotoxin assay [40] and offers the additional advantage of providing isolates for strain typing to better understand transmission dynamics in a hospital. One promising approach is the use of the highly sensitive, albeit less specific, $C$. difficile antigen assay as a screening test with a rapid turnaround time, followed by confirmatory testing of positives using a cytotoxin assay or toxigenic culture [41].

\section{Treatment strategies}

When initiating treatment for CDAD, the first basic principle is to stop the offending antimicrobial(s) if possible. In one study, $41 \%$ of patients who remained on antibiotics during treatment of CDAD with metronidazole failed, compared to none of those whose antibiotics were discontinued [42]. Therapy should be administered orally if possible, and continued for at least 10 days. Anti-peristaltic agents, including narcotics, should be avoided. For conditions such as toxic megacolon and ileus, alternative routes, such as administration of vancomycin enterally via a nasogastric tube and/or directly into the colon as an enema, should be used $[43,44]$. Finally, early surgical consultation may improve survival in selected patients with fulminant CDAD [45-47].

The two primary agents used to treat CDAD are metronidazole and oral vancomycin. Earlier randomized trials showed equivalent response rates of greater than $90 \%$ with either drug $[48,49]$. Because metronidazole is considerably less expensive than oral vancomycin and possibly less likely to promote the selection of vancomycin-resistant Enterococcus spp., practice guidelines have recommended metronidazole as first-line treatment for CDAD [50,51]. However, more recent concerns about treatment failure with metronidazole, particularly in cases of severe disease, have been raised [52,53]. In one randomized, double-blinded trial of vancomycin versus metronidazole for CDAD, cure rates were equivalent for mild CDAD (98\% and 90\% for vancomycin and metronidazole, respectively). However, for severe disease, the cure rate was significantly higher for vancomycin (97\%) than for metronidazole (76\%) [54]. Since the majority of the cases in this study occurred before recognition of the hypervirulent BI/NAP1/027 epidemic strain, it is unknown whether these findings can be generalized to the current epidemic. However, in a recent phase 3 study comparing the efficacy of the toxin binder tolevamer to vancomycin or metronidazole for CDAD, vancomycin was found to be superior to metronidazole for severe disease (defined as $\geq 10$ bowel movements/day, white blood cell count $\geq 20,001 / \mathrm{mm}^{3}$, or severe abdominal pain due to CDAD) with a clinical success rate of $85 \%$ for vancomycin versus $65 \%$ for metronidazole $(p=0.04)$ [55]. Therefore, vancomycin may be preferred as initial treatment for patients with risk factors for a complicated outcome or poor response to metronidazole, such as intensive care unit stay, low albumin level, fever, leukocytosis, profuse diarrhea, and elevated creatinine [6,54-56]. Recommendations for treatment of CDAD based on disease severity are given in Table 1 .

\section{Recurrent $C$. difficile-associated disease}

Between $15 \%$ and $35 \%$ of patients with a first episode of CDAD relapse within two months [57]. Having one recurrence puts patients at high risk for subsequent recurrences [58]. Other risk factors for recurrence include older age and decreased quality of life scores, and women appear to be more affected than men by recurrent disease [58]. An adequate serum immune response to toxin $A$ during a first episode of $C$. difficile provides protection from recurrence [15]. Reinfections with different strains of C. difficile have been found in a large proportion of recurrences, suggesting that many can be avoided by ensuring adherence to infection control measures [57].

The recommended treatment for a first recurrence is a second course of the initial therapy with either metronidazole or vancomycin. A commonly used treatment strategy for subsequent recurrences is a prolonged, tapering course of oral vancomycin, which may be followed by pulsed dosing [59]. Other strategies include combination antimicrobial therapy and efforts to restore the normal colonic flora by the use of probiotics or stool transplants. Newer antimicrobial agents and other adjunctive therapies for severe or relapsing disease are discussed below. 
Table 1

Antimicrobial Treatment for C. difficile-associated disease based on disease severity

\begin{tabular}{|c|c|}
\hline Disease classification & Recommended treatment \\
\hline $\begin{array}{l}\text { Mild to moderate disease (mild to moderate diarrhea, leukocytosis } \\
<15,000 / \mu \mathrm{l} \text { ) }\end{array}$ & Metronidazole $500 \mathrm{mg}$ orally 3 times/day for 10 to 14 days \\
\hline $\begin{array}{l}\text { Severe disease (fever, profuse diarrhea, abdominal pain, leukocytosis } \\
\geq 15,000 / \mu \text {, elevated creatinine) }\end{array}$ & Vancomycin 125 to $500 \mathrm{mg}$ orally 4 times/day for 10 to 14 days \\
\hline $\begin{array}{l}\text { Severe disease, complicated (hypotension, shock, toxic megacolon, } \\
\text { ileus) }\end{array}$ & $\begin{array}{l}\text { Vancomycin } 500 \mathrm{mg} \text { enterally by nasogastric tube and/or rectal enema } \\
4 \text { times/day with or without intravenous metronidazole } 500 \mathrm{mg} \text { every } \\
8 \text { hours }\end{array}$ \\
\hline
\end{tabular}

Adapted using data from $[6,43,44,54,56,79,92]$.

\section{New and evolving therapies}

Several newer antibiotics have been found to have good activity against C. difficile. Nitazoxanide, which is used for other gastrointestinal infections, was as effective as metronidazole in a randomized, double-blind study of hospitalized patients with CDAD [60]. Rifaximin, also used for other gastrointestinal infections, is a rifamycin-based drug that is not absorbed and achieves high fecal drug levels. It has been used in combination with vancomycin or as follow-up therapy after a course of vancomycin for patients with recurrent CDAD [61]. However, the development of rifaximin resistance is a concern, especially when the drug is used as monotherapy. In addition, resistance to rifampin in C. difficile, which accurately predicts rifaximin resistance, was found to be common among $C$. difficile isolates belonging to the epidemic BI/NAP1/027 strain in at least one institution, possibly limiting the utility of rifaximin for treating CDAD caused by this epidemic strain $[62,63]$.

The investigational drug OPT-80 (difimicin) showed promising results in treating patients with CDAD and low rates of recurrence in a phase 2 trial [64] and is currently in phase 3 trials comparing treatment efficacy with oral vancomycin. Tolevamer, a soluble anionic polymer that binds to toxins $A$ and $B$ of $C$. difficile, is a non-antibiotic therapy under investigation for treatment of CDAD and was found to be noninferior to vancomycin in treating patients with mild to moderate CDAD in a FDA phase 2 study [65]. However, preliminary results suggest it has failed to meet its noninferiority end point in a recent phase 3 trial [55]. Ramoplanin, an agent previously evaluated for eradication of vancomycin-resistant Enterococcus spp. colonization, was equally as effective as vancomycin in in vitro and hamster models of CDAD [66] and compared favorably to vancomycin for CDAD in a phase 2 clinical trial [67].

\section{Probiotics}

Adjunctive therapies for refractory disease include efforts to replenish colonic flora with the use of orally administered probiotics, usually Lactobacillus species or Saccharomyces boulardii. A recent systematic review of randomized controlled trials to evaluate the efficacy of probiotic therapies identified only two treatment studies that showed some benefit of $S$. boulardii, although the benefit was restricted to subgroups of patients with severe or recurrent CDAD [68]. A more recent randomized, controlled study found some benefit of a yogurt containing Lactobacillus spp. and Streptococcus thermophilus in the prevention of antibiotic-associated diarrhea and CDAD in patients over 50 years of age, although the applicability of the study has been questioned due to highly selective exclusion and inclusion criteria [69]. There is a concern over the safety of probiotics in severely ill or immunocompromised patients with several reports of $S$. boulardii fungemia [70] and less frequent reports of sepsis due to Lactobacillus spp. [71]. In general, there is insufficient evidence to support the routine use of probiotics to prevent or treat CDAD. Finally, case reports and case series have shown success with administration of donor stool or 'synthetic stool' (bacterial mixtures), either by nasogastric tube or colonoscopy [72-74].

\section{Immunomodulation}

Pooled human immunoglobulin contains antitoxin lgG antibodies capable of neutralizing C. difficile, and case reports have described rapid responses to intravenous immunoglobulin in patients with severe CDAD, although randomized controlled trials are needed $[75,76]$. A C. difficile toxoid vaccine has been developed and induces high level responses of serum antitoxin A lgG in healthy volunteers [77]. Further studies are needed to determine whether the vaccine responses confer protective immunity against CDAD and whether adequate immune responses are achieved in the elderly or in patients with recurrent C. difficile. Another immune therapy approach, the use of human antitoxin $A$ and $B$ monoclonal antibodies, reduced mortality in a hamster model of CDAD [78].

A detailed review of the current status of investigational therapies for CDAD was recently published by Miller [79].

\section{Prevention}

Transmission of C. difficile within hospitals has been observed through time-space clustering of new cases with identical strains and a greater risk of acquisition of $C$. difficile 
from exposure to roommates or other patients in close proximity who have positive cultures $[17,80]$. C. difficile spores have been found to contaminate the hands of healthcare workers and the hospital environment frequently $[17,81]$.

Because alcohol-based hand sanitizers do not inactivate the spores of $C$. difficile, concern over their role in transmission of $C$. difficile have been raised. However, hospitals using alcohol-based hand rubs as their primary means of hand hygiene have not seen increases in the incidence of CDAD associated with their introduction [82]. Due to the theoretical advantage of hand washing over alcohol-based hand sanitizers, hand washing with a non-antimicrobial soap or antimicrobial soap and water should be considered after removing gloves in the setting of a CDAD outbreak or if ongoing transmission cannot be controlled by other measures [83].

Patients with CDAD should be placed on contact precautions and housed in single rooms with private bathrooms or, if unavailable, cohorted in rooms with other patients with CDAD [84]. Single-use disposable or patient-dedicated noncritical equipment should be used. Wearing gloves is one measure that has been proven to reduce the spread of $C$. difficile in hospitals [85]. Gowns and gloves should be donned prior to entering the room of a patient with CDAD and removed followed by hand hygiene before leaving the room.

Although all hospital cleaning agents can inhibit the growth of C. difficile in culture, only chlorine-containing agents inactivate $C$. difficile spores. In the most definitive study evaluating environmental cleaning, the use of a 1:10 dilution of a $6 \%$ hypochlorite solution for daily room cleaning of CDAD patients in a bone marrow transplant unit decreased the CDAD rate significantly but had no effect on units with lower baseline CDAD rates [86]. Therefore, the use of hypochlorite might be most effective in units where CDAD is highly endemic. The drawbacks of hypochlorite solutions are that most of them must be prepared fresh daily and they can be caustic and damaging to hospital equipment.

Antimicrobial use restrictions are another potential mechanism of controlling and preventing $C$. difficile. As with environmental cleaning, the exact role of antimicrobial restrictions is undefined due to the presence of confounding factors in most studies. However, several studies support the use of formulary restrictions promoting the use of narrowspectrum antibiotics to reduce the incidence of CDAD [87-89]. Formulary substitutions of 8-methoxyfluoroquinolones for levofloxacin have also been proposed to control CDAD outbreaks caused by the BI/NAP1/027 strain. While this appeared to be effective in one study [90], it was ineffective in another, most likely because the overall use of fluoroquinolones in the hospital was not controlled [91].

\section{This article is part of a review series on Infection, edited by Steven Opal.}
Other articles in the series can be found online at http://ccforum.com/articles/ theme-series.asp?series=CC_Infection

Since resistance of the BI/NAP1/027 strain to fluoroquinolones is a class effect resulting in higher minimum inhibitory concentrations (MICs) to all fluoroquinolones [4], the incidence of disease caused by such resistant strains is not likely to be reduced without controlling fluoroquinolone use in general.

\section{Conclusion}

The increasing incidence and severity of CDAD in North America and Europe present major challenges for control and management of this disease. Continued gathering of data on the epidemiology of $C$. difficile through disease surveillance both within and outside of healthcare facilities, and on the efficacy of prevention and treatment strategies is essential to reduce the burden of this disease. Meanwhile, all clinicians and especially critical care physicians should maintain awareness of the changing epidemiology of CDAD and undertake measures to reduce the risk of disease in their patients.

\section{Competing interests}

The authors declare that they have no competing interests.

\section{References}

1. Bartlett JG: Antibiotic-associated pseudomembranous colitis due to toxin-producing clostridia. N Engl J Med 1978, 298: 531-534.

2. Larson HE, Price AB, Honour P, Borriello SP: Clostridium difficile and the aetiology of pseudomembranous colitis. Lancet 1978, 1:1063-1066.

3. Loo VG, Poirier L, Miller MA, Oughton M, Libman MD, Michaud S, Bourgault AM, Nguyen T, Frenette C, Kelly M, et al:: A predominantly clonal multi-institutional outbreak of Clostridium difficile-associated diarrhea with high morbidity and mortality. $N$ Engl J Med 2005, 353:2442-2449.

4. McDonald LC, Killgore GE, Thompson A, Owens RC Jr, Kazakova SV, Sambol SP, Johnson S, Gerding DN: An epidemic, toxin gene-variant strain of Clostridium difficile. N Engl J Med 2005, 353:2433-2441.

5. Muto CA, Pokrywka M, Shutt K, Mendelsohn AB, Nouri K, Posey K, Roberts T, Croyle K, Krystofiak S, Patel-Brown S, et al:: A large outbreak of Clostridium difficile-associated disease with an unexpected proportion of deaths and colectomies at a teaching hospital following increased fluoroquinolone use. Infect Control Hosp Epidemiol 2005, 26:273-280.

6. Pepin J, Valiquette L, Alary ME, Villemure P, Pelletier A, Forget K, Pepin K, Chouinard D: Clostridium difficile-associated diarrhea in a region of Quebec from 1991 to 2003: a changing pattern of disease severity. CMAJ 2004, 171:466-472.

7. Johnson S, Gerding DN: Clostridium difficile-associated diarrhea. Clin Infect Dis 1998, 26:1027-1034.

8. Kelly CP, Pothoulakis C, Lamont JT: Clostridium difficile colitis. N Engl J Med 1994, 330:257-262.

9. Limaye AP, Turgeon DK, Cookson BT, Fritsche TR: Pseudomem- 
branous colitis caused by a Toxin A- B+ strain of Clostridium difficile. J Clin Microbiol 2000, 38:1696-1697.

10. Bartlett JG: Narrative review: the new epidemic of Clostridium difficile-associated enteric disease. Ann Intern Med 2006, 145: 758-764.

11. Barbut F, Petit JC: Epidemiology of Clostridium difficile-associated infections. Clin Microbiol Infect 2001, 7:405-410.

12. Bignardi GE: Risk factors for Clostridium difficile infection. J Hosp Infect 1998, 40:1-15.

13. Kyne L, Warny M, Qamar A, Kelly CP: Asymptomatic carriage of Clostridium difficile and serum levels of IgG antibody against toxin A. N Engl J Med 2000, 342:390-397.

14. Shim JK, Johnson S, Samore MH, Bliss DZ, Gerding DN: Primary symptomless colonisation by Clostridium difficile and decreased risk of subsequent diarrhoea. Lancet 1998, 351: 633-636.

15. Kyne L, Warny M, Qamar A, Kelly CP: Association between antibody response to toxin $A$ and protection against recurrent Clostridium difficile diarrhoea. Lancet 2001, 357:189-193.

16. Viscidi R, Willey S, Bartlett JG: Isolation rates and toxigenic potential of Clostridium difficile isolates from various patient populations. Gastroenterology 1981, 81:5-9.

17. McFarland LV, Mulligan ME, Kwok RY, Stamm WE: Nosocomial acquisition of Clostridium difficile infection. $N$ Engl J Med 1989, 320:204-210.

18. Clabots CR, Johnson S, Olson MM, Peterson LR, Gerding DN: Acquisition of Clostridium difficile by hospitalized patients: evidence for colonized new admissions as a source of infection. J Infect Dis 1992, 166:561-567.

19. Johnson S, Clabots CR, Linn FV, Olson MM, Peterson LR, Gerding DN: Nosocomial Clostridium difficile colonisation and disease. Lancet 1990, 336:97-100.

20. Palmore TN, Sohn S, Malak SF, Eagan J, Sepkowitz KA: Risk factors for acquisition of Clostridium difficile-associated diarrhea among outpatients at a cancer hospital. Infect Control Hosp Epidemiol 2005, 26:680-684.

21. Archibald LK, Banerjee SN, Jarvis WR: Secular trends in hospital-acquired Clostridium difficile disease in the United States, 1987-2001. J Infect Dis 2004, 189:1585-1589.

22. McDonald LC, Owings M, Jernigan DB: Clostridium difficile infection in patients discharged from US short-stay hospitals, 1996-2003. Emerg Infect Dis 2006, 12:409-415.

23. Miller MA, Hyland M, Ofner-Agostini M, Gourdeau M, Ishak M: Morbidity, mortality, and healthcare burden of nosocomial Clostridium difficile-associated diarrhea in Canadian hospitals. Infect Control Hosp Epidemiol 2002, 23:137-140.

24. Redelings MD, Sorvillo F, Mascola L: Increase in Clostridium difficile-related mortality rates, United States, 1999-2004. Emerg Infect Dis 2007, 13.

25. Kyne L, Hamel MB, Polavaram R, Kelly CP: Health care costs and mortality associated with nosocomial diarrhea due to Clostridium difficile. Clin Infect Dis 2002, 34:346-353.

26. Kuijper EJ, Coignard B, Tull P: Emergence of Clostridium difficile-associated disease in North America and Europe. Clin Microbiol Infect 2006, 12(Suppl 6):2-18

27. Warny M, Pepin J, Fang A, Killgore G, Thompson A, Brazier J, Frost $E$, McDonald LC: Toxin production by an emerging strain of Clostridium difficile associated with outbreaks of severe disease in North America and Europe. Lancet 2005, 366:10791084.

28. Geric B, Rupnik M, Gerding DN, Grabnar M, Johnson S: Distribution of Clostridium difficile variant toxinotypes and strains with binary toxin genes among clinical isolates in an American hospital. J Med Microbiol 2004, 53:887-894.

29. MacCannell DR, Louie TJ, Gregson DB, Laverdiere M, Labbe AC, Laing F, Henwick S: Molecular analysis of Clostridium difficile PCR ribotype 027 isolates from Eastern and Western Canada. $J$ Clin Microbiol 2006, 44:2147-2152.

30. Matamouros S, England P, Dupuy B: Clostridium difficile toxin expression is inhibited by the novel regulator TcdC. Mol Microbiol 2007, 64:1274-1288.

31. Barbut F, Decre D, Lalande V, Burghoffer B, Noussair L, Gigandon A, Espinasse F, Raskine L, Robert J, Mangeol A, et al.: Clinical features of Clostridium difficile-associated diarrhoea due to binary toxin (actin-specific ADP-ribosyltransferase)-producing strains. J Med Microbio/ 2005, 54:181-185.

32. Johnson S, Samore MH, Farrow KA, Killgore GE, Tenover FC,
Lyras D, Rood JI, DeGirolami P, Baltch AL, Rafferty ME, et al.: Epidemics of diarrhea caused by a clindamycin-resistant strain of Clostridium difficile in four hospitals. N Engl J Med 1999, 341: 1645-1651.

33. Simor AE, Yake SL, Tsimidis K: Infection due to Clostridium difficile among elderly residents of a long-term-care facility. Clin Infect Dis 1993, 17:672-678.

34. Simor AE, Bradley SF, Strausbaugh LJ, Crossley K, Nicolle LE: Clostridium difficile in long-term-care facilities for the elderly. Infect Control Hosp Epidemiol 2002, 23:696-703.

35. Severe Clostridium difficile-associated disease in populations previously at low risk - four states, 2005. MMWR Morb Mortal Wkly Rep 2005, 54:1201-1205.

36. De Girolami PPC, Hanff PPA, Eichelberger KK, Longhi LL, Teresa $\mathrm{HH}$, Pratt JJ, Cheng AA, Letourneau JJM, Thorne GGM: Multicenter evaluation of a new enzyme immunoassay for detection of Clostridium difficile enterotoxin A. J Clin Microbiol 1992, 30: 1085-1088.

37. Doern GGV, Coughlin RRT, Wu LL: Laboratory diagnosis of Clostridium difficile-associated gastrointestinal disease: comparison of a monoclonal antibody enzyme immunoassay for toxins $A$ and $B$ with a monoclonal antibody enzyme immunoassay for toxin A only and two cytotoxicity assays. $J$ Clin Microbiol 1992, 30:2042-2046.

38. DiPersio JJR, Varga FFJ, Conwell DDL, Kraft JJA, Kozak KKJ, Willis DDH: Development of a rapid enzyme immunoassay for Clostridium difficile toxin $A$ and its use in the diagnosis of $C$. difficile-associated disease. J Clin Microbiol 1991, 29:27242730 .

39. Manabe YC, Vinetz JM, Moore RD, Merz C, Charache P, Bartlett JG: Clostridium difficile colitis: an efficient clinical approach to diagnosis. Ann Intern Med 1995, 123:835-840.

40. Delmee M, Van BJ, Simon A, Janssens M, Avesani V: Laboratory diagnosis of Clostridium difficile-associated diarrhoea: a plea for culture. J Med Microbiol 2005, 54:187-191.

41. Reller ME, Lema CA, Perl TM, Cai M, Ross TL, Speck KA, Carroll $\mathrm{KC}$ : Yield of stool culture with isolate toxin testing versus a two-step algorithm including stool toxin testing for the detection of toxigenic Clostridium difficile. J Clin Microbiol 2007, 45: 3601-3605.

42. Modena S, Gollamudi S, Friedenberg F: Continuation of antibiotics is associated with failure of metronidazole for Clostridium difficile-associated diarrhea. J Clin Gastroenterol 2006, 40:49-54.

43. Pasic M: Intracolonic vancomycin for pseudomembranous colitis. N Engl J Med 1993, 329:583.

44. Apisarnthanarak A, Razavi $B$, Mundy LM: Adjunctive intracolonic vancomycin for severe Clostridium difficile colitis: case series and review of the literature. Clin Infect Dis 2002, 35:690-696.

45. Dobson G, Hickey C, Trinder J: Clostridium difficile colitis causing toxic megacolon, severe sepsis and multiple organ dysfunction syndrome. Intensive Care Med 2003, 29:1030.

46. Synnott K, Mealy K, Merry C, Kyne L, Keane C, Quill R: Timing of surgery for fulminating pseudomembranous colitis. $\mathrm{Br} J$ Surg 1998, 85:229-231.

47. Lamontagne $F$, Labbe $A C$, Haeck $O$, Lesur $O$, Lalancette $M$, Patino C, Leblanc M, Laverdiere M, Pepin J: Impact of emergency colectomy on survival of patients with fulminant Clostridium difficile colitis during an epidemic caused by a hypervirulent strain. Ann Surg 2007, 245:267-272.

48. Teasley DG, Gerding DN, Olson MM, Peterson LR, Gebhard RL Schwartz MJ, Lee JT Jr: Prospective randomised trial of metronidazole versus vancomycin for Clostridium difficileassociated diarrhoea and colitis. Lancet 1983, 2:1043-1046.

49. Wenisch C, Parschalk B, Hasenhundl M, Hirschl AM, Graninger W: Comparison of vancomycin, teicoplanin, metronidazole, and fusidic acid for the treatment of Clostridium difficile-associated diarrhea. Clin Infect Dis 1996, 22:813-818.

50. Gerding DDN, Johnson SS, Peterson LLR, Mulligan MME, Silva $\mathrm{JJ}$ : Clostridium difficile-associated diarrhea and colitis. Infect Control Hosp Epidemiol 1995, 16:459-477.

51. No authors listed: Recommendations for preventing the spread of vancomycin resistance. recommendations of the Hospital Infection Control Practices Advisory Committee (HICPAC). MMWR Recomm and Rep 1995, 44:1-13.

52. Musher DM, Aslam S, Logan N, Nallacheru S, Bhaila I, Borchert F, Hamill RJ: Relatively poor outcome after treatment of Clostrid- 
ium difficile colitis with metronidazole. Clin Infect Dis 2005, 40:1586-1590.

53. Pepin J, Alary ME, Valiquette L, Raiche E, Ruel J, Fulop K, Godin $D$, Bourassa C: Increasing risk of relapse after treatment of Clostridium difficile colitis in Quebec, Canada. Clin Infect Dis 2005, 40:1591-1597.

54. Zar FA, Bakkanagari SR, Moorthi KMLST, Davis MB: A comparison of vancomycin and metronidazole for the treatment of Clostridium difficile-associated diarrhea, stratified by disease severity. Clin Infect Dis 2007, 45:302-307.

55. Louie T, Gerson M, Grimard D, Johnson S, Poirier A, Weiss K, Peppe J, Donovan J, Davidson D, for the Polymer Alternative for CDAD Treatment (PACT) Investigators: Results of a phase III trial comparing tolevamer, vancomycin and metronidazole in patients with Clostridium difficile-associated diarrhea (CDAD). In Programs and Abstracts of the 47th Interscience Conference on Antimicrobial Agents and Chemotherapy; Chicago IL. American Society for Microbiology; September 17-20, 2007.

56. Fernandez A, Anand G, Friedenberg F: Factors associated with failure of metronidazole in Clostridium difficile-associated disease. J Clin Gastroentero/ 2004, 38:414-418.

57. Barbut F, Richard A, Hamadi K, Chomette V, Burghoffer B, Petit JC: Epidemiology of recurrences or reinfections of Clostridium difficile-associated diarrhea. J Clin Microbiol 2000, 38: 2386-2388.

58. McFarland LV, Surawicz CM, Rubin M, Fekety R, Elmer GW, Greenberg RN: Recurrent Clostridium difficile disease: epidemiology and clinical characteristics. Infect Control Hosp Epidemiol 1999, 20:43-50.

59. McFarland LV, Elmer GW, Surawicz CM: Breaking the cycle: treatment strategies for 163 cases of recurrent Clostridium difficile disease. Am J Gastroenterol 2002, 97:1769-1775.

60. Musher DM, Logan N, Hamill RJ, Dupont HL, Lentnek A, Gupta A, Rossignol JF: Nitazoxanide for the treatment of Clostridium difficile colitis. Clin Infect Dis 2006, 43:421-427.

61. Johnson S, Schriever C, Galang M, Kelly CP, Gerding DN: Interruption of recurrent Clostridium difficile-associated diarrhea episodes by serial therapy with vancomycin and rifaximin. Clin Infect Dis 2007, 44:846-848.

62. Curry SR, Marsh JW, Muto CA, Pasculle AW, Harrison LH: Rifampin non-susceptibility associated with epidemic BI/NAP1 C. difficile isolates in Pittsburgh, PA 2001-6. In Programs and Abstracts of the 47th Interscience Conference on Antimicrobial Agents and Chemotherapy; Chicago, IL. American Society for Microbiology; September 17-20, 2007.

63. Galang MA, Hecht DW, Sambol SP, Gerding DN, Johnson S: Rifampin susceptibility by agar dilution and Etest predicts susceptibility to rifaximin in Clostridium difficile. In Programs and Abstracts of the 47th Interscience Conference on Antimicrobial Agents and Chemotherapy; Chicago, IL. American Society for Microbiology; September 17-20, 2007.

64. Louie T, Miller M, Donskey C, Mullane K, Goldstein EJC, Corrado M, Lee C, Okumu F, Gorbach S, Sears P, et al:: Safety, pharmacokinetics and outcomes of PAR-101 in healthy subjects and patients with Clostridium difficile-associated diarrhea. In Program and Abstracts of the 45th Interscience Conference on Antimicrobial Agents and Chemotherapy; Washington, DC. American Society for Microbiology; December 16-19, 2005.

65. Louie TJ, Peppe J, Watt CK, Johnson D, Mohammed R, Dow G, Weiss K, Simon S, John JF Jr, Garber G, et al.: Tolevamer, a novel nonantibiotic polymer, compared with vancomycin in the treatment of mild to moderately severe Clostridium difficile-associated diarrhea. Clin Infect Dis 2006, 43:411-420.

66. Freeman J, Baines SD, Jabes $\mathrm{D}$, Wilcox $\mathrm{MH}$ : Comparison of the efficacy of ramoplanin and vancomycin in both in vitro and in vivo models of clindamycin-induced Clostridium difficile infection. J Antimicrob Chemother 2005, 56:717-725.

67. Pullman J, Prieto J, Leach TS: Ramoplanin vs. vancomycin in the treatment of Clostridium difficile diarrhea: a phase 2 study. In Program and Abstracts of the 44th Interscience Conference on Antimicrobial Agents and Chemotherapy; Washington, DC. American Society for Microbiology; October 30-November 2, 2004.

68. Dendukuri N, Costa V, McGregor M, Brophy JM: Probiotic therapy for the prevention and treatment of Clostridium difficile-associated diarrhea: a systematic review. CMAJ 2005, 173:167-170.

69. Hickson M, D'Souza AL, Muthu N, Rogers TR, Want S, Rajkumar
C, Bulpitt CJ: Use of probiotic Lactobacillus preparation to prevent diarrhoea associated with antibiotics: randomised double blind placebo controlled trial. BMJ 2007, 335:80-86.

70. Muñoz PP, Bouza EE, Cuenca-Estrella MM, Eiros JMJM, Pérez MJMJ, Sánchez-Somolinos MM, Rincón CC, Hortal JJ, Peláez TT: Saccharomyces cerevisiae fungemia: an emerging infectious disease. Clin Infect Dis 2005, 40:1625-1634.

71. Hammerman C, Bin-Nun A, Kaplan M: Safety of probiotics: comparison of two popular strains. BMJ 2006, 333:1006-1008.

72. Aas J, Gessert CE, Bakken JS: Recurrent Clostridium difficile colitis: case series involving 18 patients treated with donor stool administered via a nasogastric tube. Clin Infect Dis 2003, 36:580-585.

73. Persky SE, Brandt $\amalg$ : Treatment of recurrent Clostridium difficile-associated diarrhea by administration of donated stool directly through a colonoscope. Am J Gastroenterol 2000, 95: 3283-3285.

74. Tvede M, Rask-Madsen J: Bacteriotherapy for chronic relapsing Clostridium difficile diarrhoea in six patients. Lancet 1989, 1: 1156-1160.

75. Salcedo J, Keates S, Pothoulakis C, Warny M, Castagliuolo I, Lamont JT, Kelly CP: Intravenous immunoglobulin therapy for severe Clostridium difficile colitis. Gut 1997, 41:366-370.

76. Beales IL: Intravenous immunoglobulin for recurrent Clostridium difficile diarrhoea. Gut 2002, 51:456.

77. Aboudola S, Kotloff KL, Kyne L, Warny M, Kelly EC, Sougioultzis S, Giannasca PJ, Monath TP, Kelly CP: Clostridium difficile vaccine and serum immunoglobulin $G$ antibody response to toxin A. Infect Immun 2003, 71:1608-1610.

78. Babcock GJ, Broering TJ, Hernandez HJ, Mandell RB, Donahue K, Boatright N, Stack AM, Lowy I, Graziano R, Molrine D, et al:: Human monoclonal antibodies directed against toxins $A$ and B prevent Clostridium difficile-induced mortality in hamsters. Infect Immun 2006, 74:6339-6347.

79. Miller MA: Clinical management of Clostridium difficile-associated disease. Clin Infect Dis 2007, 45(Suppl 2):S122-S128.

80. Chang VT, Nelson K: The role of physical proximity in nosocomial diarrhea. Clin Infect Dis 2000, 31:717-722.

81. Dubberke ER, Reske KA, Noble-Wang J, Thompson A, Killgore G, Mayfield JL, Camins B, Woeltje K, McDonald JR, McDonald LC, et al.: Prevalence of Clostridium difficile environmental contamination and strain variability in multiple health care facilities. Am J Infect Control 2007, 35:315-318.

82. Boyce JM, Ligi C, Kohan C, Dumigan D, Havill NL: Lack of association between the increased incidence of Clostridium difficile-associated disease and the increasing use of alcohol-based hand rubs. Infect Control Hosp Epidemiol 2006, 27:479-483.

83. Boyce JM, Pittet D: Guideline for hand hygiene in health-care settings: recommendations of the Healthcare Infection Control Practices Advisory Committee and the HICPAC/SHEA/ APIC/IDSA Hand Hygiene Task Force. Infect Control Hosp Epidemiol 2002, 23(12 Suppl):S3-40.

84. Siegel JD, Rhinehart E, Jackson M, Chiarello L, and the Healthcare Infection Control Practices Advisory Committee: Guideline for Isolation Precautions: Preventing Transmission of Infectious Agents in Healthcare Settings 2007 [http://www.cdc.gov/ncidod/dhqp/pdf/guidelines/lsolation2007.pdf]

85. Johnson S, Gerding DN, Olson MM, Weiler MD, Hughes RA, Clabots CR, Peterson LR: Prospective, controlled study of vinyl glove use to interrupt Clostridium difficile nosocomial transmission. Am J Med 1990, 88:137-140.

86. Mayfield JL, Leet T, Miller J, Mundy LM: Environmental control to reduce transmission of Clostridium difficile. Clin Infect Dis 2000, 31:995-1000.

87. Fowler S, Webber A, Cooper BS, Phimister A, Price K, Carter $Y$, Kibbler CC, Simpson AJH, Stone SP: Successful use of feedback to improve antibiotic prescribing and reduce Clostridium difficile infection: a controlled interrupted time series. J Antimicrob Chemother 2007, 59:990-995.

88. Ho M, Yang D, Wyle FA, Mulligan ME: Increased incidence of Clostridium difficile-associated diarrhea following decreased restriction of antibiotic use. Clin Infect Dis 1996, 23(Suppl 1): S102-S106.

89. McNulty C, Logan M, Donald IP, Ennis D, Taylor D, Baldwin RN, Bannerjee M, Cartwright KA: Successful control of Clostridium difficile infection in an elderly care unit through use of a restric- 
tive antibiotic policy. J Antimicrob Chemother 1997, 40:707-711.

90. Gaynes R, Rimland D, Killum E, Lowery HK, Johnson TM, Killgore G, Tenover FC: Outbreak of Clostridium difficile infection in a long-term care facility: association with gatifloxacin use. Clin Infect Dis 2004, 38:640-645.

91. Biller P, Shank B, Lind L, Brennan M, Tkatch L, Killgore G, Thompson A, McDonald LC: Moxifloxacin therapy as a risk factor for Clostridium difficile-associated disease during an outbreak: attempts to control a new epidemic strain. Infect Control Hosp Epidemiol 2007, 28:198-201.

92. Sunenshine RH, McDonald LC: Clostridium difficile-associated disease: new challenges from an established pathogen. Cleve Clin J Med 2006, 73:187-197. 